European journal of American studies

Special Issue: Truth or Post-Truth? Philosophy, American Studies, and Current Perspectives in

Pragmatism and Hermeneutics

\title{
Creating New Pasts: Reality, Facticity and Interpretation in Peirce and Heidegger
}

\section{Susanne Rohr}

\section{OpenEdition \\ Journals}

\section{Electronic version}

URL: https://journals.openedition.org/ejas/15604

DOI: 10.4000/ejas.15604

ISSN: 1991-9336

Publisher

European Association for American Studies

\section{Electronic reference}

Susanne Rohr, "Creating New Pasts: Reality, Facticity and Interpretation in Peirce and Heidegger",

European journal of American studies [Online], 15-1 | 2020, Online since 11 May 2020, connection on 08 July 2021. URL: http://journals.openedition.org/ejas/15604 ; DOI: https://doi.org/10.4000/ejas.15604

This text was automatically generated on 8 July 2021.

Creative Commons License 


\title{
Creating New Pasts: Reality, Facticity and Interpretation in Peirce and Heidegger
}

\author{
Susanne Rohr
}

1 The relationship between Peirce and Heidegger, or between Peirce's pragmatism and Heidegger's hermeneutics of facticity, is not a happy one. It is a love story that could easily have been but never was. And only recently have the striking parallels between the two philosophies been fully acknowledged and assessed-the profound differences that, of course, exist between them, notwithstanding. In what follows, I will draw relationships between the central assumptions of the two theories and establish between them what can be called a dialogue.

2 The disregard or even rejection of pragmatism in German philosophy is quite surprising given that pragmatism had a swift and very hopeful start at the III. International Congress for Philosophy held in Heidelberg in 1908, when it dominated the conference as its main topic. As a result of this congress, pragmatism became known to Germany's philosophy scene and the first publications began to appear, such as Günther Jacoby's 1909 Der Pragmatismus. Neue Bahnen in der Wissenschaftslehre des Auslands. Eine Würdigung. In his foreword, Jacoby points out that, not surprisingly, it is the unusual concept of truth that constitutes the core of the most profound controversies in both the US and European philosophy.

3 The outbreak of World War I abruptly ended the lively debates on pragmatism and truth, and it is one of the most remarkable, if not lamentable, facts that this debate was not taken up again for a very long time. If pragmatism was acknowledged at all in that long period-which arguably ended when Richard Rorty's Consequences of Pragmatism was published in 1982, reigniting the interest in pragmatism in Germany-it was mainly in a vulgarized version, devoid of sophistication, featuring many anti-American prejudices and misconceptions.

4 The Frankfurt School is a case in point. Max Horkheimer, for instance, presumably had not read any original texts, but even in his American exile still insisted on a policy of 
separatism and not taking American philosophy seriously. As Martin Jay points out: "This allowed it [The Frankfurt School] to make assumptions, such as the equation of pragmatism with positivism, that lacked complete validity. It also cut the Institut off from potential allies in the American intellectual tradition, such as George Herbert Mead" (289). A notable exception on the German scene is Arnold Gehlen's Der Mensch. Seine Natur und seine Stellung in der Welt, published in 1940. It acknowledges pragmatism's potential in conceptualizing the subject as genuinely interactive and directed towards the other. Gehlen points out that pragmatism is "the only philosophy to date that fundamentally sees man as a being that acts" and, furthermore, "that the basic structure of all mental phenomena is action directed towards another." ${ }^{1}$

5 Tracing the convoluted reception of pragmatism in the German context, Heidegger undoubtedly plays the most unfortunate role. While today, as I have pointed out, many similarities between his existential philosophy and pragmatism have been acknowledged, Heidegger himself is an example of the prejudiced and misguided discussions which monopolized German philosophy since the 1920s. In an interview with Rudolf Augstein, editor of the German news magazine Der Spiegel that took place in 1966 but was only published posthumously in 1976, Heidegger typically equates pragmatism with positivism and holds that the Americans "are still caught up in a thought (Pragmatism) which favors functions and manipulations" ("Only a God Can Save Us" 43).

6 Klaus Oehler recalls a meeting with Heidegger, in which the philosopher stated that pragmatism "was nothing but a Weltanschauung for engineers and not for human beings in the full sense of the word" (33). This blatant expression of anti-Americanism is all the more regrettable as it completely misses out on the many intersections between Heidegger's hermeneutics and pragmatism's main concerns. And it is to these points of overlap that I will now turn in order to establish a dialogue between the two approaches. Let me begin, however, by pointing out that in my discussion of pragmatism I will mainly concentrate on the writings of its founder, Charles Sanders Peirce, and only sporadically consider the pragmatist versions of other thinkers.

7 Assessing the general profile of both Heidegger's phenomenological ontology and the pragmatism of Peirce, a shared core concern becomes apparent: the rejection of the traditional dichotomy of realism and idealism. ${ }^{2}$ Both thinkers seek to situate their theories in a place beyond these philosophical traditions, and they each bring man's knowing of the world and the being of man in the world together, although imbedded in their different theoretical layout and argumentative structures. Heidegger takes the route via his crucial definition of understanding which to him is a fundamental mode of Being, conceptualized as Being-in-the-world or Dasein. Being is not something stableand I will return to this characteristic shortly-but must be understood as a dynamic process, as the condition for the emergence of entities and world out of concealment into unconcealment.

8 Discussing Heidegger's "hermeneutics of facticity" in contrast to competing hermeneutical perspectives, eminent Heidegger exegete Hans-Georg Gadamer underscores the centrality of Heidegger's definition of the concept of understanding:

Understanding is not a resigned ideal of human experience adopted in the old age of the spirit, as with Dilthey; nor is it, as with Husserl, a last methodological ideal of philosophy in contrast to the naivete of unreflecting life; it is, on the contrary, the original form of the realization of Dasein, which is being-in-the-world. Before any differentiation of understanding into the various directions of pragmatic or 
theoretical interest, understanding is Dasein's mode of being, insofar as it is potentiality-for-being and "possibility" [...]. Understanding is the original characteristic of the being of human life itself. (Truth and Method 250)

9 To return to the realism vs. idealism tradition, here both Heidegger's and Peirce's examination of Kant's transcendental philosophy is, of course, of major importance. In discussing Kant's crucial definition of the thing-in-itself, Heidegger presents the view that we encounter entities only in virtue of the world within which they can be disclosed. Furthermore, the thing is independent of Dasein, but not in such a way as to be independent of the sense structure for its understanding. In his rainbow metaphor, Peirce makes the same claim: "everything which is present to us is a phenomenal manifestation of ourselves. This does not prevent its being a phenomenon of something without us, just as a rainbow is at one a manifestation both of the sun and of the rain" (5.283). ${ }^{3}$ In Heidegger's approach, the experience of a thing reveals its structure, to which Dasein has an anticipatory relation. To return to Gadamer again for a moment, he sees this as a crucial move in the hermeneutics of facticity as for him it was only the "confrontation with the incomprehensibility of factive Being itself," a core assumption of Heidegger's thinking, that "constituted a break with the idealist notion of hermeneutics." (Hermeneutik II 323; my translation, S.R.)

10 I argue that the pragmatic maxim, the core of pragmatist philosophy, serves the same function, as it describes how the direct experience of an object, the examination of its function, practical consequences, and the use we make of it reveals its meaning. The pragmatic maxim reads as follows: "Consider what effects, that might conceivably have practical bearings, we conceive the object of our conception to have. Then, our conception of these effects is the whole of our conception of the object" (5.402). The crucial difference is, of course, that, for Peirce, factive Being is not incomprehensible but endlessly comprehensible, in an unlimited flow of interpretations. Still, the two theories are closely connected with regard to this essential element: For both Peirce and Heidegger hold that to understand a thing, to get its meaning, one has to grasp the pattern of those activities or possibilities into which the thing is typically involved and into which one is led when using the thing.

11 In Heidegger's and Peirce's particular definitions of the interrelations between consciousness and object, of knower and known, the role of pre-scientific experience comes into play. It seems to me that here, in their corresponding conceptualization of this initial involvement as anticipatory structure we find a particularly important congruence between the two approaches, and I would call them their respective "hermeneutical core." For in Peirce's approach, idealist and realist positions also converge, and this happens in the dimension of pre-scientific experience. Following realist positions, Peirce sees reality as genuinely open to knowledge, yet from idealism he adopts the view that this knowledge can only be in signs. Hence his definition: "what we think of cannot possibly be of a different nature from thought itself. For the thought thinking and the immediate thought-object are the very same thing regarded from different points of view" (6.339). This causes him to see reality not as the starting point of interpretation but as its final result, a strictly semiotic process that relies on anticipatory structures akin to Heidegger's.

12 For all sign processes according to Peirce rely on an initial moment of informed guessing which Peirce calls abductive inference, a procedure that encompasses "all the operations by which theories and conceptions are engendered" (5.590). In abductive 
inferences, subjective and culturally predetermined elements converge that determine the result: an assumption about what might be the case, a guess at the riddle. In this perspective, reality in its initial moment of constitution is the result of informed guessing. True to pragmatist philosophy, this process also encompasses an intersubjective dimension, as reality is a decidedly communal product:

The real, then, is that which, sooner or later, information and reasoning would finally result in, and which is therefore independent of the vagaries of me and you. Thus the very origin of the conception of reality shows that this conception essentially involves the notion of a COMMUNITY [sic], without definite limits, and capable of a definite increase of knowledge. (5.311)

13 As these descriptions show, the semiotic dimension is crucial in both approaches, and its implications are significant. Both Peirce and Heidegger understand the subject as situated in language, thus Being and Dasein for Heidegger is as fundamentally mediated as it is for Peirce for whom existence is always already mediated by semiosis. As such, both Dasein and existence are constituted in and as moments of sign interpretations, forever evolving as they are situation-bound and thus open to re-interpretation at any moment. Only temporarily do they congeal into knowledge.

Correlating Heidegger's and Peirce's perspectives, Klaus Oehler describes the vulnerability of the process as follows: "The future reveals a new reality, and in the light of a new reality the past also takes on a new appearance. While travelling forward into a new reality in the future, man is at the same time on his way into a new past. As existence is illuminated in this way, truth comes into being" (31). Both Dasein and existence, that is, present themselves as paradoxical conditions, they are retrospective and future-oriented at the same time. For it is in continuously creating new pasts that we establish knowledge and truth, which makes these relative to a context and therefore genuinely temporal. The two-faced situatedness of human existence as seen in its temporal dimension was also explored extensively by William James in his pragmatist analysis of the human perception of time, who found the following powerful image for capturing it:

the practically cognized present is no knife-edge, but a saddle-bag, with a certain breadth of its own on which we sit perched, and from which we look in two directions into time. The unit of composition of our perception of time is a duration, with a bow and a stern, as it were-a rearward- and a forward-looking end. (609)

Returning to Peirce and Heidegger, I would now like to look more closely at the theoretical basis of assessing the precariousness of human life and see how both philosophers develop their respective argument. It all starts with a particular mode of taking in and interacting with the world. Let me explain.

In 1955, Heidegger in his "Memorial Address" for the composer Conradin Kreutzer made a distinction between "calculative" and "meditative" reasoning, pleading for the latter modality. ${ }^{4} \mathrm{He}$ laments the dominance of calculative thinking which, he claims, makes us a "perplexed victim at the mercy of the irresistible superior power of technology" ("Memorial Address" 52-53) and furthermore holds it responsible for what he sees as the thoughtlessness of his time. Thereby, as I would argue, Heidegger uncannily comments on our present situation as well: "All of us, including those who think professionally, as it were, are often enough thought-poor; we all are far too easily thought-less.... For nowadays we take in everything in the quickest and cheapest way, only to forget it just as quickly, instantly" ("Memorial Address" 45). The media as one 
of the main facilitators of this kind of being in the world, "give the illusion of a world that is no world" ("Memorial Address" 48).

What, then, is gained by comparison in practicing meditative thinking? To Heidegger, but also to Peirce, it is of utmost importance, as this mode is the basis and starting point for all systematic, controlled thinking. As such, it is the condition for new developments, including scientific discovery. For discovery relies on creativity, on a certain openness towards the phenomena that is characteristic of meditative thinking. To quote Heidegger: "Meditative thinking demands of us not to cling one-sidedly to a single idea, nor to run down a one-track course of ideas" ("Memorial Address" 55). Developments and discoveries thus demand of us "that we engage ourselves with what at first sight does not go together at all" ("Memorial Address" 55). What is more, a certain aesthetic dimension will then open up in the process as well, for it is only in meditative thinking, Heidegger claims, that we then "notice that a work of art has flowered in the ground of our homeland" ("Memorial Address" 47). As an intermediate result we might say at this point that facticity in this perspective both presents itself to us and is created by us as a work of art.

Peirce describes the same process-the process of abductive inference already mentioned above-along similar lines. For him, it is the "idea of putting together what we had never before dreamed of putting together" (5.181), he calls it "reverie with some qualification" and "Pure Play" (6.458) in which the mind searches for connections:

It begins passively enough with drinking in the impression of some nook in one of the three Universes [of experience: mere Ideas, Brute Actuality, Signs]. But impression soon passes into attentive observation, observation into musing, musing into a lively give and take of communion between self and self. If one's observations and reflections are allowed to specialize themselves too much, the Play will be converted into scientific study. (6.459)

For both Heidegger and Peirce, this passive-active interplay of impression and reflection constitutes an anticipatory structure, a fore-understanding and an orientation of the mind to receive.

Having a closer look at Peirce's theory now, we first need to recognize that it is persistently ordered by dependency, so that his entire theoretical architecture is structured by a strict hierarchy in which the highest elements incorporate and are genuinely shaped by those elements on which they rest. In his classification of the sciences, for instance, Metaphysics depends on and is influenced by Phenomenology, and Logic rests on Aesthetics. Phenomenology again provides the three universal categories, and the order of dependency determines that Thirdness as the category of sign relations, of mediation and language, is dependent on and encompasses both Secondness-or mere being and experience-and Firstness-or pure quality and impression. In terms of their modality, that of Thirdness is necessity, that of Secondness reality, and Firstness's modality is possibility. As the order of dependency implies, reality, for instance, as a product of sign processes and thus representing Thirdness by necessity incorporates elements of pure quality and reveals an aesthetic dimension. Translated into the categories of consciousness, the implication would be in the Peircean system that every thought has an affective quality. ${ }^{5}$ As Heidegger would have it, calculative reasoning is dependent on feeling or meditative reasoning. 
21 How, then, do we describe the infrastructure of the transition from meditative to calculative reasoning and back again? The issue here seems to be a phenomenological one, as it consists of coming to terms with the various forms of experience, particularly in their first and pre-scientific form. Phenomenology's function, Peirce stresses, is to

make out what [...] the elements of appearance that present themselves to us every hour and every minute [are], whether we are pursuing earnest investigations or are undergoing the strangest vicissitudes of experience, or are dreamily listening to the tales of Scheherezade. (Pragmatism as a Principle and Method of Right Thinking 152)

However, as both Peirce and Heidegger maintain, this task of identifying and classifying the elements of experience that continuously flood our perceptions is not an easy one, for the intimate nearness and familiarity of the initial encounter makes them hard to grasp. Thus, when we ask about the precise nature of the present instance, the question, for Peirce, "always comes too late" (1.310). Similarly, Heidegger argues that it is not distance but rather proximity that conceals: "the way to what is near is always the longest and thus the hardest for us humans" ("Memorial Address" 53).

But how do we get there, how do we distance ourselves from the elements of our perception and at the same time stay close to them? How do we let the world go at the same time that we firmly embrace it in acts of re-creation? Peirce's answer is precise: the "artist's observational power is what is most wanted in the study of phenomenology" (5.42). And this power is the capacity of creativity, of abductive inference, it is the "idea of putting together what we had never before dreamed of putting together" (5.181), as I have already quoted. Very much in the same vein, Heidegger demands "that we engage ourselves with what at first sight does not go together at all" ("Memorial Address" 53). In this way contemplative thinking is set into motion and the phenomena of the world appear to us as a work of art. As already indicated, for both Peirce and Heidegger, this is a paradoxical process that requires to be passive and active at the same time: "we let ourselves into releasement to thatwhich-regions, we will non-willing" ("Conversation on a Country Path" 79). That the phenomena appear in the aesthetic dimension finds a correlative dimension in our response as the qualitative feel of the object. ${ }^{6}$

But to return to Heidegger and Peirce and to the next step in the process from meditative to calculative thinking-the following step is the need to identify the percepts. I am quoting Peirce again: What is now needed is "the resolute discrimination which fastens itself like a bulldog upon the particular feature that we are studying, follow[ing] it wherever it may lurk, and detect[ing] it beneath all its guises" (5.42). This requires yet again a paradoxical mindset or mode, as it depends on the coexistence of both patience and persistence, or the artist's sensitivity and the bulldog's resoluteness. Heidegger makes quite a similar claim when in "Conversation on a Country Path About Thinking" he suggests passivity as tenor--he instructs us to wait and act at the same time and proposes the concept of "non-willing," meaning "willingly to renounce willing" ("Conversation on a Country Path" 59) to reach a "thinking that is not a willing" ("Conversation on a Country Path" 60). Then "out of the view which [the horizon] encircles, the appearance of objects comes to meet us" ("Conversation on a Country Path" 65).

This, however, is not yet the end of the transition from meditative to calculative thinking, as generating categories is now necessary. Peirce describes the final step as follows: "the third faculty we shall need is the generalizing power of the mathematician 
who produces the abstract formula that comprehends the very essence of the feature under examination" (5.42). There is one quality that facilitates the transition from complete openness to controlled thinking and accompanies it along the way: It is, as Peirce calls it, the attitude of agape, or love for truth. "It is not by dealing out cold justice to the circle of my ideas that I can make them grow, but by cherishing and tending them as I would the flowers in my garden" (6.289), Peirce writes. For Heidegger, it is the attitude of "concernedness" (Sorge) that plays the same role. Phenomenology, that is, needs the willed-unwilled disposition of an open mind, and this in turn needs the agape of the thinker.

If we return to the question of object formation for a moment, another point of intersection between the two theories becomes apparent. As I have already indicated above when I presented Peirce's conceptualization of the real as the product of semiotic processes, the dimension of intersubjectivity as well as the communal aspect are inevitably inherent there. For the real, let me repeat, is not the starting point, but the product of processes of sign interpretations. Every sign, due to the hierarchical structure of Peirce's philosophy, by necessity entails subjective as well as culturally predetermined patterns of interpretation that are shared by a particular culture at a particular time. By introducing the concept of "references" (Verweisungen), Heidegger, for his part, establishes the communal and intersubjective connection. References can be understood as the relation things have to each other and to the human mind by being connected in practical concerns. For example, a nail only makes sense "in reference to" a hammer. ${ }^{7}$ According to Heidegger, caring for these everyday things is crucial because this discloses the Being of the being, discloses Dasein. What is also important here is the connective power inherent in references. For the individual is limitless in terms of the references he or she might be affected by, and this limitlessness connects individuals into communities. The individual is not seen as independent self, but as someone who, in incorporating Dasein, is always already connected with others by way of the many references that implicate the individual. ${ }^{8} \mathrm{So}$, while, as Heidegger holds, being is prior to beings, tending to or caring for the many references that connect objects and persons constitutes Dasein in all of its dimensions and facets. For worldliness is embeddedness, and something gets meaning only by virtue of being caught up in an ensemble of relations.

I would now like to turn to the final concept of this essay that I have, until now, only considered in passing: the question of truth. For Peirce, processes of sign interpretation tend to evolve towards truthful interpretations that are socially shared. Thus, realityand truth-are consensual products. "Final opinions," Peirce calls them, "that which, sooner or later, information and reasoning would finally result in" (5.311). However, although these opinions are consensual and by definitionem fallible, they are not relative or formed as needed, as typical accusations of pragmatism would have it, but selfcorrecting and guided by common sense. Truth, in Peirce's perspective, functions as a regulatory element in public discourse and is a product of the universal method that inevitably underlies all processes of thinking and interpretation, be those individual or communal, private or scientifically controlled, evolving unconsciously or as a conscious procedure. While this method rests on creative guessing, a particularly uncertain ground, it nonetheless secures the self-correcting quality of the result as well. According to Peirce, the universal method consists of the process of first abductively generating explanatory hypotheses about what might be the case, that are then revised in inductive and deductive examination, only to start anew, endlessly. The potentially 
endless progression of this sequence generates interpretations that approximate truth as faulty or questionable elements are continuously combed out inductively and deductively.

The discussion of the nature of truth plays a large part in Heidegger's philosophical oeuvre as well. As with most of his essential concepts, he develops a specific terminology in the discussion, in this case he refers back to the ancient concept of alētheia, meaning "unconcealment" or Unverborgenheit in German. Unconconcealment belongs primordially to Dasein, as Dasein unfolds in events of uncovering, that is, in moments where the meaning of a phenomenon is uncovered for the individual and by the individual. ${ }^{9}$ Akin to Peirce's pragmatist view which I have just sketched, these moments are carried out by interpretation and thus require creativity, as unconcealment is about creating a context within which things can be what they are. This constitutes the first and crucial step towards truth, or change from concealment to unconcealment, and facilitates the transition from the pre-predicative experience of things into the possibility of articulating experience in propositions..$^{10}$ For Peirce, abductive inference serves the very same function as it transfers percepts, or sense impressions, into perceptual judgments, or hypotheses, that can then be examined inductively and deductively, as explained above. Finally, for both Peirce and Heidegger, these moments of transition involve a subjective as well as an intersubjective, social dimension, for tradition and history influence the constitution of propositions as individuals share the public knowledge of their age, or, as Heidegger calls it, are part of "publicity" (Öffentlichkeit).

As such, depending on the realms of discourse individuals share, they can certainly go wrong in their acts of unconcealment-particularly when presented "alternative facts" from sources they trust.

\section{BIBLIOGRAPHY}

Anderson, Douglas. "Peirce and Heidegger: A Shared Concern." Philosophy Today, vol. 30, no. 2, 1986, pp. 119-125.

Bourgeois, Patrick L., and Sandra B. Rosenthal. "Heidegger and Peirce: Beyond 'Realism or Idealism."' Southwest Philosophy Review, vol. 4, no. 1, 1984, pp. 103-110.

Farin, Ingo, and Jeff Malpas, editors. Reading Heidegger's Black Notebooks 1931-1941. MIT P, 2016.

Gadamer, Hans-Georg. Truth and Method. $2^{\text {nd }}$ revised ed., translation revised by Joel Weinsheimer and Donald G. Marshall, Continuum, 2006.

---. Gesammelte Werke. Band 2. Hermeneutik II: Wahrheit und Methode. Ergänzungen. Register. $2^{\text {nd }}$ revised ed., Mohr, 1993.

Gehlen, Arnold. Der Mensch: Seine Natur und seine Stellung in der Welt. Junker und Dünnhaupt, 1940. 
Heidegger, Martin. "Conversation on a Country Path about Thinking." Discourse on Thinking: A Translation of Gelassenheit. Translated by John M. Anderson and E. Hans Freund, Harper \& Row, 1966, pp. 58-90.

---. "Memorial Address." Discourse on Thinking: A Translation of Gelassenheit. Translated by John M. Anderson and E. Hans Freund, Harper \& Row, 1966, pp. 43-57.

---. “Only a God Can Save Us: Der Spiegel's Interview with Martin Heidegger (September 23, 1966)." Translated by Maria P. Alter and John D. Caputo. Philosophical and Political Writings, edited by Manfred Stassen, Continuum, 2003, pp. 24-48.

---. Sein und Zeit. $15^{\text {th }}$ revised ed., Niemeyer, 1979.

Innis, Robert E. "Perception, Interpretation, and the Signs of Art." The Journal of Speculative Philosophy, vol. 15, no. 1, 2001, pp. 20-32.

Jacoby, Günther. Der Pragmatismus: Neue Bahnen in der Wissenschaftslehre des Auslands: Eine Würdigung. Dürr, 1909.

James, William. The Principles of Philosophy. Vol. 1, Dover Publications, 1950.

Jay, Martin. The Dialectical Imagination: A History of the Frankfurt School and the Institute of Social Research, 1923-1950. Little, Brown and Co., 1973.

Kockelman, Paul. "Four Theories of Things: Aristotle, Marx, Heidegger, and Peirce." Signs and Society, vol. 3, no. 1, 2015, pp. 153-192.

Koskela, Jani. “Truth as Unconcealment in Heidegger's Being and Time." Minerva: An Internet Journal of Philosophy, vol. 16, 2012, pp. 116-128.

Oehler, Klaus. "Notes on the Reception of American Pragmatism in Germany, 1899-1952." Transactions of the Charles S. Peirce Society, vol. 17, no. 1, 1981, pp. 25-35.

Peirce, Charles Sanders. Collected Papers of Charles Sanders Peirce. Edited by Charles Hartshorne and Paul Weiss (vols. I-VI) and Arthur W. Burks (vols. VII and VIII), Harvard UP, 1931-34 and 1958.

---. Pragmatism as a Principle and Method of Right Thinking. The 1903 Harvard Lectures on Pragmatism. Edited by Patricia Ann Turrisi, State U of New York P, 1997.

Wrathall, Mark A. Heidegger and Unconcealment: Truth, Language, and History. Cambridge UP, 2011.

\section{NOTES}

1. Quoted in Oehler 29. Translated by Oehler.

2. Cf. also Bourgeois, and Rosenthal.

3. Peirce, Charles Sanders. Collected Papers of Charles Sanders Peirce. References to the Collected Papers are generally made in the form of decimal quotation, i.e. indicating volume and paragraph. Thus, a number like the above '5.283' points to volume V, § 283 . Hereafter, I will only give the decimal quotation when referring to the Collected Papers.

4. For a more detailed discussion of this distinction cf. Anderson. The concept of "calculative thinking" can be traced in Heidegger's anti-Semitic remarks on "World Jewry" in his Black Notebooks. These private musings, which Heidegger kept for more than forty years, constitute a very difficult context. When the notebooks from 1931 to 1941 were published in 2014, they immediately sparked international controversy for they showed for the first time how profoundly Heidegger's anti-Semitism shaped his philosophical thinking. This poses the question of how, then, we are to engage with an important philosophy that seems contaminated by anti- 
Semitism? While I do not wish to enter this debate here, I want to acknowledge its urgency. Cf. Farin, and Malpas.

5. Robert E. Innis discusses Peirce's concept of the aesthetic dimension as follows: "Indeed, for Peirce the mind of the interpreter is a 'topos' or 'place' or 'space' where the 'play' of interpretants takes place. We are 'in' the play rather than the play being in us-Gadamer's position exactly" (26).

6. Dewey again saw this and made this qualitative affinity between a feeling and a form the cornerstone of his pragmatist aesthetics, where it constitutes the preanalytic apprehension of significance that then goes over into the analytic or hermeneutic phase.

7. On Heidegger's account of references cf. Kockelmann 166-167.

8. Heidegger's term for the intersubjective condition is „Mitsein.“ In Sein und Zeit he writes: „Die Welt des Daseins ist Mitwelt. Das In-Sein ist Mitsein mit Anderen. Das innerweltliche Ansichsein dieser ist Mitdasein“(118).

9. My account of alētheia and truth refers to the way Heidegger develops this connection in Being and Time, in other words, before the turn. Cf. also Koskela.

10. Wrathall describes concealment as "a nonassertoric dealing with the world in the sense that, in such pre-predicative comportments, the world is experienced in a way that lacks determinacy, that is, propositional articulation" (19).

\section{ABSTRACTS}

Only recently have the striking parallels between Charles S. Peirce's pragmatism and Martin Heidegger's hermeneutics of facticity been fully acknowledged and assessed-the profound differences that, of course, exist between them, notwithstanding. This essay draws relationships between the central assumptions of the two theories and establishes between them what can be called a dialogue.

\section{INDEX}

Keywords: pragmatism; hermeneutics; epistemology; interpretation; Truth; Martin Heidegger; Charles S. Peirce

\section{AUTHOR}

\section{SUSANNE ROHR}

Susanne Rohr is Chair of North American Literature and Culture at the University of Hamburg. She has published widely in the fields of literary and cultural theory, semiotics, American pragmatism, epistemology, and on a broad range of topics in American literature of the 19th and 20th centuries. 